\title{
Psychiatric nursing: analysis of the Manual Cuidados aos Psychopathas
}

\author{
Enfermagem psiquiátrica: análise do Manual Cuidados aos Psychopathas \\ Enfermería psiquiátrica: análisis del Manual de Cuidados aos Psychopathas \\ Cláudia Polubriaginof*; Paulo Fernando Souza Campos**
}

\begin{abstract}
Context: The study evokes the institutionalization of Psychiatry in Sao Paulo, Brazil , in the early twentieth century. Objectives: To analyze the psychiatric nursing care practices, based on the manual Cuidados aos Psychopathas, in the Juquery Hospital, a renowened mental health institution in Brazil and Latin America.

Methodology: This is an historical analysis based on the document review of the manual Cuidados aos Psychopathas, published in 1930 by Antônio Carlos Pacheco e Silva, who was, at the time, the hospital director.

Results: The manual, with its 138 pages, is the first Brazilian publication written in Portuguese focused on Psychiatric Nursing.

Conclusion: Nursing was instrumental in consolidating the asylum assistance model and practices, especially those performed by professionals without formal Nursing training, which were characterized by force and implementation of medical knowledge regardless of the patients' identity and individuality.
\end{abstract}

Keywords: history of nursing; psychiatric hospital; psychiatric nursing

\section{Resumo}

Contexto: O estudo evoca a institucionalização da Psiquiatria em São Paulo, Brasil, no início do século XX. Objetivos: Analisar os cuidados de enfermagem psiquiátrica no Hospital do Juquery, a partir do manual Cuidados aos Psycopathas e quais as práticas que foram utilizadas no espaço manicomial tido por excelência no Brasil e na América Latina, o Hospital do Juquery.

Metodologia: Trata-se de uma análise histórica realizada a partir da pesquisa documental do manual intitulado Cuidados aos Psychopathas publicado em 1930 por Antônio Carlos Pacheco e Silva, então diretor do hospital.

Resultados: Composto por 138 páginas o livro é a primeira publicação brasileira em língua portuguesa destinada à enfermagem psiquiátrica.

Conclusão: A enfermagem foi fundamental na consolidação do modelo asilar e as práticas exercidas principalmente dos que não receberam preparação formal para o exercício da enfermagem caracterizaram uma prática marcada pela força e a execução do saber médico à revelia da identidade e da individualidade dos doentes.

Palavras-chave: história da enfermagem; hospital psiquiátrico; enfermagem psiquiátrica

\footnotetext{
* RN, Santo Amaro University, 04743030, São Paulo, Brazil [claudiaenfhist@gmail.com]. Contribution to the article: literature search; identification and analysis of sources; article writing Address for correspondence: Rua Clark, 70, Apto. 252, São Paulo, 04743030, Brasil. ** PhD., Professor, Santo Amaro University, 04743030, São Paulo, Brazil [pfsouzacampos@ hotmail. $\mathrm{com}]$. Contribution to the article: article supervision; indication of bibliographic references; source analysis; article revision.
}

\section{Resumen}

Contexto: El estudio evoca la institucionalización de Psiquiatría en Sao Paulo, Brasil, a principios del siglo XX. Objetivos: Analizar los cuidados de enfermería psiquiátrica en el Hospital Juquery a partir del Manual de Cuidados aos Psychopathas, así como qué prácticas se utilizaron en el hospital psiquiátrico de excelencia en Brasil y América Latina, el Hospital Juquery.

Metodología: Se trata de un análisis histórico realizado a partir de la investigación documental del manual titulado Atención a Psicópatas, publicado en 1930 por Antonio Carlos Pacheco e Silva, entonces director del hospital.

Resultados: El libro está compuesto por 138 páginas y se trata de la primera publicación brasileña en portugués destinada a la enfermería psiquiátrica.

Conclusión: La enfermería fue fundamental en la consolidación del modelo de asilo y las prácticas ejercidas, sobre todo de aquellos que no recibieron preparación formal para el ejercicio de la enfermería, caracterizaron una práctica marcada por la fuerza y la ejecución del saber médico sin tener en cuenta la identidad y la individualidad de los pacientes.

Palabras clave: historia de la enfermería; hospital psiquiátrico; enfermería psiquiátrica

Received for publication: 15.09 .15

Accepted for publication: 18.03 .16 


\section{Introduction}

The historical analysis of the establishment and functioning of Psychiatric Nursing in the Juquery Hospital, in the city of São Paulo, aims at analyzing the psychiatric nursing care and practices at this institution based on the manual Cuidados aos Psychopathas. This hospital was a renowned mental health institution not only in Brazil but also in the whole Latin America. Specifically, we focused our analysis on the proposals of Antônio Carlos Pacheco e Silva for psychiatric nursing care by analyzing the manual Cuidados aos Psychopathas, published in 1930 (Pacheco e Silva, 1930). This manual, which guided the nursing practices in the Juquery hospital, has not yet been analyzed in historiographic studies, including by nurse researchers who study the history of Nursing.

We chose the psychiatric nursing practice as study object due to its clear importance in the process of developing and consolidating the hygienist model of exclusion, within the care domain, which at the time could also be characterized as an asylum-type care. In this setting, ruled by institutionalization, exclusion and moral treatment, nursing played a key role. According to Pereira (2002, p. 37), it was argued that "the basic ingredients for moral treatment are a good nurse, a good cook and a nice view".

Since the colonial period of Brazilian history, the organization of mental health care was a responsibility of the nurses or of people assuming their functions, either in the application of disciplinary procedures for patients to comply with the clinical indications or in the maintenance of the asylum order. The psychiatric organization proposed by French psychiatrists was incorporated in Brazilian psychiatry since the end of the $18^{\text {th }}$ century. In the second half of the $19^{\text {th }}$ century, conditions were created for hospices to become a place of production of knowledge on madness and a way to cure it (Kirschbaun, 1997).

Therefore, we formulate the following questions: How did Pacheco and Silva define the nursing staff and their practices when writing and publishing a manual for this purpose, and How did the proposals of the renowned psychiatrist guided nursing care and the relationships between physicians, nurses and patients.

\section{Methodology}

The historical analysis is based on the document review of the manual entitled Cuidados aos Psychopathas, written by Antônio Carlos Pacheco e Silva and published by Officinas Graphicas do Hospital do Juquery in 1930, being held in the Prof. Carlos da Silva Lacaz Historical Museum archives of the Faculty of Medicine of the University of São Paulo. The procedure can be characterized as an important qualitative research technique based on the extraction of descriptive data and on the researcher's direct and interpretative approach to the source (Neves, 1996).

\section{Results and Discussion}

During his 13-year mandate as director of the Juquery Psychiatric Hospital, Pacheco e Silva published articles, books, manuals, and organized compendiums in Psychiatry, which were published in Brazil and other countries. In 1930, Pacheco e Silva published what he called the little book, composed of 138 pages and entitled Cuidados aos Psychopathas. According to the author, the book, which is considered one of the first manuals focused on psychiatric care in the $20^{\text {th }}$ century, was the first Brazilian publication written in Portuguese intended for Psychiatric Nursing. The author's first argument for writing the manual was related to the underdevelopment of Brazilian Nursing, i.e. this was the reason for focusing his research on this topic. According to Pacheco e Silva, there was a dissonance between the advances of Nursing in Brazil when compared to other countries which he had visited and where he had studied:

In Brazil, the Nursing profession has not yet reached the same level as in European countries and in the United States; particularly in relation to the nurses in hospitals for psychopaths, our country suffers from a lack of professionals with the required basic knowledge for a good performance of their mission. (Pacheco e Silva, 1930, Preamble)

By analyzing the document, we can see that the author stressed the relevance of the manual, as well as its recipient - the nurse -, stating that "in no other place is his action more necessary and essential than in 
hospitals for psychopaths." (Pacheco e Silva, 1930, p. Preamble). The arguments used by the physician point to a criticism of the status conferred to psychiatric nursing in Brazil, which had been excluded from the professional training of reference, originated in Rio de Janeiro. In the document, besides portraying nursing using the male form, which abandoned the prevalent representations of that time, the author leads us to reflect on the importance of nursing in relation to a new treatment approach suggested by the Juquery Psychiatric Hospital. In his words:

With this new guidance, the role of the nurse whether male or female - has gained increasing importance. In permanent contact with patients, the nurse must also put into practice the valuable resources of moral therapy, comforting them, inspiring trust in recovery and surrounding them with the greatest warmth (Pacheco e Silva, 1930, p. 3)

Moral therapy was the basis for the treatment provided in psychiatric hospitals and was strongly influenced by European psychiatry, especially the French practice. Highly relevant at that time was the fact that the author stripped away the gender condition imposed by current standards at that time to Brazilian professional training in nursing, which was founded in the feminization of care (Campos \& Oguisso, 2013). By identifying the gender identity assigned by his proposed new guidelines, that is, male or female, the author argues that the standard proposed as ideal for Brazilian nursing was not hegemonic, since it was an area of excellence in psychiatric treatment.

However, when discussing the nurses' role in the treatment of mental disorders, the author clearly demonstrates the condition of subservience that nurses should maintain in relation to the medical knowledge. Pacheco and Silva represents the nurses' status, their skills and daily practices within hospital settings as being closely linked to medical practices while being completely kept under its authority. Even considering the precariousness of professional training and the low level of knowledge of the men and women who worked as nurses at the Juquery Hospital, the predominant discourse rejected the possibility of unauthorized intervention.

It is also the nurse's responsibility to make sure that patients follow the physician's prescriptions, while ensuring that they do not do anything silly. Notwithstanding, it should be noted that, although very knowledgeable in his trade, the nurse must never overstep his duties. The nurse's every action should be guided by medical orientation and he should never, under any circumstance, deviate from the recommendations received (Pacheco e Silva, 1930, p. 3-4)

Medicine has a high social representation, being recognized by society as intrinsically associated with the field of science. The same applies to the scientific knowledge it produces, especially in areas of diagnosis of illness, treatments and, consequently, possibilities of cure. In turn, care is the guiding principle in nursing knowledge and practice. In this context, the discussion on the lack of professional nursing training, particularly in psychiatry, has permeated the political arena since the 1920s, even when schools and models were defended based on a standard proposed as ideal. Despite this, nursing practice was, as mentioned above, represented as subordinate to medical knowledge/authority, while possessing its specific set of knowledge.

The manual presents the main psychiatric disorders, briefly summarizing signs, symptoms and treatments. These descriptions, sometimes pejorative and clearly judgmental, move away from the illness itself and become bound to the patient, as if the illness was affected by the patient and not the opposite, i.e., as if the illness was naturally vulnerable to certain types of human beings, whose adverse ways of life and work would lead them to deviation, disorganization, and illness. An example of this was the so-called pathological drunkenness, observed in predisposed, deviant and epileptic individuals, in whom alcohol wakened violent urges, during which the individual becomes destructive and bloodthirsty, committing murders and criminal acts, only calming down after the intoxication has passed: "the individual vomits and remains in the gutters or roads for hours, where he not rarely finds death, ran over by a vehicle or drowned in floods." (Pacheco e Silva, 1930, p. 15).

In this process, the analyzed document considers that the relationship between society and the patient with mental disorder was categorized by the concept of normality and abnormality. In this way, the established representations about the mad person and madness have determined the association of pathologies to deviant and promiscuous behaviors. Additionally, patients with mental disorders had to be separated, even excluded, from the social environment before 
they committed any crime, because they were naturally delinquent or half-way to madness, alluding to the French notion of demi-fou.

In the third chapter of the manual, the author systematically highlights the nursing practices, describing the initial care provided to psychopatbs, with guidelines divided into two components: collection of the patient's prior history, and importance of constant surveillance. As regards the patient's history, though focused on the determinist and hereditary perspective of the illness/patient, the author suggests the possibility of what is known today as patient screening in the form of primary care. This excerpt of the manual points to the possibility of the nurse's more effective intervention in order to allow the patient to recover his/her prior life:

The first care intervention of the person to whom a psychopath is entrusted should be to investigate the main acts previously committed by the patient, his predominant ideas, etc. The hereditary factors should also be thoroughly investigated, questioning his relatives, friends, work colleagues and physicians who have treated him before the onset of the mental illness. (Pacheco e Silva, 1930, p. 30)

Surveillance is an essential characteristic of the asylum. The nursing role incorporates a network of observation extended to the whole hospital setting. The analyzed document mentions the difference of the surveillance performed at the asylum, which is a central surveillance, spatially characterized and focused on the principle of inspection:

The patient shall be thoroughly searched to ensure that he has no hidden object with which he could harm himself or others. One of the more practical ways to do this search is by asking the patient to take a bath. Meanwhile, another person, out of the patient's sight, shall search all his clothes, emptying the pockets, taking note of the contents. The patient's writings, notebook, papers, etc., as absurd as their contents may seem, should be kept and delivered to the physician, who often finds in them valuable elements for his observation. (Pacheco e Silva, 1930, p. 30)

In the modern psychiatric hospital, the nurse is responsible for surveillance and control. It is the nurse who must accompany the patients to all places, establishing a link between care, which is specific to nursing, and constant surveillance, which is a relevant function since hospital admission. With the consolidation of modern psychiatry, the domain produced by madness and for madness implied considering different diagnoses. Although moral madness justified institutionalization, the life inside the asylum and the therapeutic measures applied within its walls exacerbated the deviations, if they already existed.

However, surveillance shall be performed discreetly, so as not to irritate the patient. Any abnormality noticed should be immediately brought to the physician's attention. The observing and conscientious nurse can assist the physician, providing information about the patient's behavior during the first days of hospitalization. (Pacheco e Silva, 1930, p. 33-4)

Despite the nurse's subordinate position to a higher instance, the excerpt allows confirming that the physician's procedures were anchored in nursing practice, which was essential to the medical intervention. Through their surveillance, the nurses provided information on the events, which served as basis for the treatment prescribed by the physicians. However, the proposed nursing practices were similar to those of the guards in the pavilions that existed in the general facilities, the judiciary asylum, the school for people with mental disabilities, and other sectors of the Juquery complex:

Supervisors shall oversee the nurses and guards of the corresponding pavilion. They shall see how each of them behaves. They shall take hold of all the keys of all nurses and guards who are off-duty and away from the hospital. (Pacheco e Silva, 1930, p. 113)

In the chapters describing the most common and recommended therapies for psychiatric treatment at the time, the author describes in detail several guidelines regarding, for example, the number of employees and their functions, description of material and medication dosing. In the fourth chapter, entitled "Dietetics. Artificial feeding. Nutrient enema", Pacheco e Silva describes the nursing practices regarding the patient's organism. When addressing the issue of artificial feeding, the author emphasizes that "Whenever a patient refuses to eat, he should be confined to bed" (Pacheco and Silva, 1930, p. 38), while also stating that such procedure should be carried out only as a last resource. However, the description of the procedure allows considering 
the nurse's intervention: "The nurse should be accompanied by other people, to restrain the most recalcitrant patients" (Pacheco e Silva, 1930, p. 39). The procedure consisted of a nasogastric intubation, inserting a $50 \mathrm{~cm}$ tube through the nose or mouth to feed the patient with liquid-food.

We can assess the psychiatric nursing practices in another excerpt of the manual, where the author describes "Pharmacotherapy". Along with the information on the medical practice, such as the prescription of medication, administration routes, dosing and adverse effects, as well as any specific instructions, particularly related to treatment compliance, the physician's intervention allows considering the nurse's intervention when stating that:

The nurse should dissolve the medication in enough water and ask a colleague to help by pinching the patient's nose. The patient will have to open his mouth to breath, and will swallow the liquid with the medication. (Pacheco e Silva, 1930, p. 44)

When addressing the use of medication, if the administration involved the handling of needles and syringes, the manual discouraged the nurse's intervention considering that nurses lacked training and technical and scientific knowledge to deal with any complication arising from relatively complex procedures. At the same time, in the eighth chapter, among the recommendations for the special care provided to patients who were agitated, dirty, epileptic or being treated for malaria or tuberculosis, the author emphasizes the need for the nursing team to maintain physical distance from the patient, advocating that:

The nurse should not enter the [patient's] room, unless it is absolutely necessary. Epileptic [patients], when not suffering seizures, are, as a rule, impulsive, violent and aggressive, therefore extreme patience is recommended, trying not to irritate them (Pacheco e Silva, 1930, p. 73)

Although the medical discourse was marked by a sense of zeal or, occasionally, gentleness, patients were subjected to repression, taking into account that:

Psychiatry tries to disassociate its practice from the mad person who violently marks, hurts and mutilates the body. The means of repression are activated to achieve amenability. They do not aim to mark the body, but to turn the violent body into a peaceful body. (Machado, Loureiro, Luz, \& Muricy, 1978, p. 445)

In the last chapter, entitled "Hospitals for psychopaths. New orientation toward assistance and treatment of mental patients. The nurse's duties", the author extends the possibilities of analysis and recognition of the nursing practices implemented in the hospital setting. The physician starts by describing the new hospital:

The modern psychopathic hospitals are very comfortable, and are provided with laboratories and specialized medical services, where mental patients are carefully examined. If a patient becomes agitated and aggressive or destructive, he is isolated and submitted to balneotherapy. The nurses care for them in a gentle way, without using mechanical means of restraint (straitjacket, etc.). (Pacheco e Silva, 1930, p. 109-10)

Throughout his text, Pacheco e Silva stresses the importance of this new way of caring for the patient, an activity in which the nurse plays an essential role. However, at that time and in that context, being a nurse was almost a synonym to being a guard: "All guards who have proved to be competent and possess hospital practice shall be designated as 'nurses', and all those who are receiving training shall be entitled "nurse assistants"'" (Pacheco e Silva, 1930, p. 115). Nursing professionals, even if formal training was still incipient in the country, were responsible for managing the asylum according to the medical design. The function of the guard/nurse was governed by the medical model of exclusion/confinement:

In these institutions, the nurse plays a key role, being responsible for the liaison between the medical-administrative team and the patient. Hence, the great importance that the faithful performance of his duties has in the normal functioning of major psychopathic hospitals. For this reason, three major aspects are essential: competence, order and discipline. The service becomes extremely simplified if each nurse pledges to dutifully comply with his duties. (Pacheco e Silva, 1930, p. 111)

Pacheco e Silva clearly explained to all applicants who sought work at the Hospital the need for a medical examination and the signature of a Statement of Commitment, in which they committed themselves to respecting and complying with all the decisions 
of the Director of the institution. These decisions were not limited to the daily hospital work, but they went beyond the walls of Juquery. Concerning the employee's time off or absences, the physician emphasized that:

Employees shall not exit the hospital, in any circumstance, without proper authorization. Employees shall not enter the facilities after 10 pm. Supervisors shall oversee the nurses and guards of the corresponding pavilion. They shall take hold of all the keys of all nurses and guards who are off-duty and away from the hospital. No employee shall receive payment of wages when no longer working at the hospital without first returning the uniform and any objects belonging to the institution that may be in his possession. (Pacheco e Silva, 1930, p. 112-3

It should be noted that the Juquery Hospital was founded as a pioneering institution and that the main goal of Antônio Carlos Pacheco e Silva was to turn the attention to the institution, especially as a center for scientific production. To this end, the renowned physician considered nursing to play an important role in achieving his objectives. The publication of this manual explicitly refers his intentions.

In 1923, Antônio Carlos Pacheco e Silva took over the administration of the Juquery Hospital. His management is barely mentioned in recurrent historiography. Thus, the consulted documents allow accessing new information about the history of mental health and psychiatry in the period under analysis. From a broader perspective, the analysis of the administration of Pacheco e Silva recalls an important part of the process of modernization underwent by the Juquery Hospital at the time.

The Juquery Hospital was founded in 1898 in a public farm, near the train station of the historic São Paulo Railway, in a public farm, and aimed at treating mental disorders. A pioneer institution in Brazil, the hospital was designed according to the hygienist principles, being an important milestone, from the ethical, social and cultural perspectives, in Brazilian psychiatry and worldwide (Cunha, 1986).

With his conservative ideology, a characteristic reflected in his lectures and publications, Pacheco e Silva reaffirmed the maintenance of the status quo of society's most wealthy groups, by imposing the ideological and moral order of the Brazilian elite at the time. Associated with the organicist theories for explaining mental disorders, Pacheco e Silva was, throughout his career, opposed to the use of psychoanalysis and other non-medical therapies, and introduced most of the so-called biological therapies, such as electroconvulsive therapy, in Brazil (Tarelow, 2012).

Pacheco e Silva started his medical training at the first Faculty of Medicine of São Paulo, in the private Universidade Livre de São Paulo. Upon the impending closure of this institution, he completed his degree at the Faculty of Medicine of Rio de Janeiro, in 1920. This same year, he travelled to Europe seeking the specialization in Neuropsychiatry, attending classes of renowned experts, such as the French neurologist Pierre Marrie (1853-1940), and took part in internship programs in the Hospitals of Salpetrière and Sant'Anna, in France. In Switzerland, he took courses taught by Eugen Bleuler (1857-1939), the Swiss psychiatrist known for introducing the term schizophrenia to designate what was formerly known as dementia praecox. In Germany, he learned with Emil Kraepelin (1856-1926), the psychiatrist who is commonly considered as the founder of modern psychiatry, psychopharmacology and psychiatric genetics, and who argued that psychiatric disorders were caused by genetic and biological disorders (Tarelow, 2012).

Mental disorder is perceived as a disturbance at the level of passions and will, which explained the need for medical intervention and nursing care. In this sense, the medical knowledge justified the interference of a specialized diagnosis that considered the individual to be ill when he broke up the network of relationships seen as normal, by unbalancing and subverting, through his excesses, the rules that governed society. Associated with crime and violence, mental disorders postulated the ideology of surveillance and control, as guiding principles of care and care practices. This influenced the intervention of the nurses, who were mostly men and who were also identified in the manual as guards, alluding to the French term garde malade. Many of them had no specific training or previous formal experience to perform functions as nurses at the Juquery Hospital.

When analyzing the manual Cuidados aos Psychopathas, we can consider that, within the routine psychiatric practices, the relationships of power, knowledge, subordination and professional status between medical and nursing professionals 
have always been and still are asymmetrical - either because the physician historically holds the important and recognized power to heal, resulting from his intellectual capital, widely recognized by society, or because this does not apply to nursing, which, after being recognized as a science, has not gained the same professional status and value in society. Hence the subordination of the nursing team to the medical team, considering that nursing has emerged as a profession marked by a social-cultural-historical background that comprised the gender issue and its consequent subordination, as well as the non-legitimatization of the nursing knowledge and practice. In addition, the health organizations enabled the advancement of the medical field to the detriment of the nurses' knowledge.

Although many of these assumptions have been revoked, the recurrent idea still persists that our behaviors and moral judgments, how we connect with others and ourselves are inextricably associated with the ideas constructed about what is and is not normal. These ideas can be found in everyday life, thereby greatly influencing the medical-psychiatric knowledge about all issues related to the human being.

\section{Conclusion}

The political, economic and social changes that occurred in Brazil in the turn of the $20^{\text {th }}$ century were decisive for the consolidation of psychiatry and nursing in Brazil. This period was characterized by the import of knowledge and technologies for the construction, organization and functioning of psychiatric hospitals, the treatment of patients, as well as for addressing the health problems of the population, with an emphasis on eugenics and mental hygiene.

The trajectory of Brazilian nursing was marked by contradictions, as it was a legally recognized liberal profession, but dependent on the labor market, which was dominated by women. Therefore, psychiatric nursing stood apart in the provision of care to psychiatric patients, particularly in the implementation of disciplinary medical procedures in order to subject patients to the proposed standardization and to the maintenance of the asylum organization. In this sense, the nursing professionals were essential to the consolidation of the asylum assistance model. However, the practices performed mainly by those professionals without formal nursing training characterized a practice marked by the use of force and the implementation of medical knowledge without taking into account the identity and individuality of patients with mental disorders.

\section{References}

Campos, P. F., \& Oguisso, T. (2013). Enfermagem no Brasil: Formação e identidade profissional pós -1930. São Caetano do Sul, Brasil: Yendis.

Cunha, M. C. (1986). O espelho do mundo: Juquery, a bistória de um asilo. Rio de Janeiro, Brasil: Paz e Terra.

Kirschbaun, D. I. (1997). Análise histórica das práticas de enfermagem no campo da assistência psiquiátrica no Brasil, no período compreendido entre as décadas de 20 e 50. Revista Latino-Americana de Enfermagem, 5(spe), 1930. doi: 10.1590/S0104-11691997000500003

Machado, R., Loureiro, A., Luz, R., \& Muricy, K. (1978). Aos loucos o hospício. In R. Machado, A. Loureiro, R. Luz, \& K. Muricy (Eds.), Danação da norma: A medicina social e constituição da psiquiatria no Brasil (pp. 423-485). Rio de Janeiro, Brasil: Graal.

Neves, J. L. (1996). Pesquisa qualitativa: Características, usos e possibilidades.Caderno de pesquisas em administração, 1(3). Retrieved from http://www.unisc.br/portal/upload/ com_arquivo/pesquisa_qualitativa_caracteristicas_usos_e possibilidades.pdf

Pacheco e Silva, A. C. (1930). Cuidados aos psychopathas. São Paulo, Brasil: Officinas Graphicas do Hospital do Juquery.

Pereira, L. M. (2002). Os primeiros sessenta anos da terapêutica psiquiátrica no estado de São Paulo. In E. H. Antunes, L. H. S. Barbosa \& L. M. F. Pereira (Eds.), Psiquiatria, loucura e arte: Fragmentos da bistória brasileira (pp. 33-54). São Paulo, Brasil: EDUSP.

Tarelow, G. Q. (2012). Entre febres, comas e convulsões: As terapias biológicas no Hospital do Juquery administrado por Pacheco e Silva (1923-1937) (Master's thesis). Universidade de São Paulo, Faculdade de Filosofia, Letras e Ciências Humanas, Brasil. 
